\title{
HUBUNGAN ANTARA LOCUS OF CONTROL INTERNAL DENGAN KEMATANGAN KARIR PADA SISWA SMK N 1 BANTUL
}

\author{
Ninik Widyastuti, Arini Widyowati \\ FakultasPsikologi \\ Universitas Ahmad Dahlan \\ Jl. Kapas No. 09 Yogyakarta \\ ninik.psikologi@gmail.com
}

\begin{abstract}
This study aims to determine the relation between internal locus of control with career maturity of students in vocational high school (SMK) Negri 1 Bantul. The research involved 150 eleventh-grade students of five classes in SMK Negri 1 Bantul as samples that were chosen using cluster random sampling. Data was collected using career maturity scale and internal locus of control scale and Pearson Product Moment correlation technique with SPSS 16.0 for Windows was used to analyze the data. The results showed that the coefficient correlation between those two variables reach at $r=0.161$ and $p=0.049(\mathrm{p}<0.05$ $=$ significant). It can be concluded that there is a significant positive relationship between internal-locus of control and students's career maturity. The higher students' internal locus of control, the higher students' career maturity and vice versa.
\end{abstract}

Keywords: career maturity, career-planning, internal locus of control.

\begin{abstract}
Abstrak
Penelitian ini bertujuan untuk mengetahui hubungan atara locus of control internal dengan kematangan karir pada siswa Sekolah Menengah Kejuruan (SMK) Negri 1 Bantul. Sampel penelitian adalah siswa kelas XI SMK Negri 1 Bantul yang berjumlah 150 siswa dari 5 kelas yang dipilih secara acak dengan menggunakan teknik cluster random sampling. Pengumpulan data dilakukan dengan menggunakan skala kematangan karir dan skala locus of control internal. Data dianalisis dengan menggunakan teknik analisis korelas Product Moment dari Pearson melalui program SPSS 16.0 for windows. Hasil analisis data menunjukkan koefisien korelasi antara dua variabel sebesar $r=0,161$ dan $p=0,049$ ( $\mathrm{p}<0,05=$ signifikan). Berdasarkan hasil penelitian, dapat disimpulkan bahwa terdapat hubungan positif yang signifikan antara locus of control internal dengan kematangan karir pada siswa SMK N 1 Bantul. Semakin tinggi locus of control internal pada siswa, semakin tinggi kematangan karirnya. Sebaliknya, semakin rendah locus of control internal siswa, maka semaki rendah kematangan karirnya.
\end{abstract}

kata kunci: kematangan karir, locus of control internal, perencanaan karir. 


\section{Pendahuluan}

Persaingan global membuat perusahaan dan lapangan pekerjaan lain meningkatkan kualitas perusahaan dengan menerima karyawan yang sesuai dengan tujuan.Dalam menghadapi persaingan ekonomi dunia, perusahaan berusaha untuk mendapatkan karyawan yang memiliki kompetensi yang tinggi. Hal ini berdampak pada persyaratan yang tinggi bagi calon karyawan. Oleh karena itu, calon karyawan harus mampu menyiapkan kompetisinya sejak dini agar siap menghadapi persaiangan di dunia kerja.

Menyiapkan kompetensi individu merupakan salah satu peran institusi pendidikan. Pendidikan mengajarkan pengetahuan, keterampilan sikap dan perilaku yang mendukung individu untuk dapat mencapai tujuan karir dan menyelesaikan permasalahan dalam kehidupannya. Salah satu lembaga pendidikan yang mempersiapkan siswanya untuk siap memasuki dunia kerja adalah SMK (Sekolah Menengah Kejuruan). SMK merupakan tingkat pendidikan yang setara dengan SLTA. Sesuai dengan Surat Keputusan Direktur Jenderal Manajemen Pendidikan Dasar dan Menengah Nomor: 251/C/KEP/MN/2008 tanggal 22 Agustus 2008 tentang Spektrum Keahlian Pendidikan Menengah Kejuruan, program pendidikan pada SMK dikelompokkan menurut bidang studi keahlian.

Super (Fuhrmann, 1990) SMK lebih memberikan wadah untuk remajaremaja yang siap untuk kerja, atau ingin mematangkan kemampuannya di bidang tertentu untuk nantinya lebih siap menata karirnya, siswa kelas XII berada pada tahap eksplorasi periode kristalisasi. Pada masa ini remaja mulai mengidentifikasi kesempatan dan tingkat pekerjaan yang sesuai, serta mengimplementasikan pilihan karir dengan memilih pendidikan dan pelatihan yang sesuai, akhirnya memasuki pekerjaan yang sesuai dengan pilihannya

Dalam mempersiapkan karir, beberapa permasalahan sering dialami para siswa disekolah, salah satunya adalah ketidakmampuan dalam menentukan tujuan karir. Menurut FIP-UPI (2007) seorang siswa hendaknya memiliki perencanaan karir agar dapat mempersiapkan pedidikan, karir, tujuan sosial-pribadi yang didasarkan atas pegetahuan akan dirinya, informasi tentang sekolah, dunia kerja, dan masyarakatnya. Siswa juga seharusnya mampu merumuskan rencana untuk mencapai tujuan jangka pendek, jangka menengah dan tujuan jangka panjang. Kesulitan dalam beradaptasi dengan tugas-tugas perkembangan karir ini, akan berdampak pada kegagalan dan rasa frustrasi ( Winkel \& Hastuti, 2007).

Menurut data yang diperoleh dari BPS (Badan Pusat Statistik), tingkat pengangguran terbuka (TPT) berdasarkan tingkat pendidikan; pada Agustus 2014, TPT untuk pendidikan Sekolah Menengah Kejuruan menempati posisi tertinggi yaitu sebesar 11,24\%, disusul oleh Sekolah Menengah Atas sebesar 9,55\%, yang sebelumnya pada Agustus 2013 diperoleh TPT Sekolah Menengah Kejuruan sebesar 11,21\% dan TPT pada Sekolah Menengah Atas sebesar 9,72, yang berarti TPT pada SMK mengalami kenaikan sebesar 0,04\% per 2013-1014. Tingginya angka pengangguran di Indonesia diduga karena kurangnya kemampuan individu dalam mempersiapkan karir.

Kemampuan individu dalam mempersiapkan karirnya berhubungan dengan kematangan karir. Betz dan Luzo (1996) mendefinisikan kematangan karir sebagai kemampuan dalam menguasai tugas kejuruan, termasuk pengetahuan 
dan komponen sikap, sesuai dengan tahap pengembangan karir. Kematangan karir mengukur tingkat kesiapan klien untuk menguasai tugas-tugas pengembangan karir (Savickas, 2001).

Super (Winkel, 2004) mendefinisikan kematangan karir sebagai kemampuan individu untuk menyelesaikan tugas-tugas perkembangan karir yang khas pada tahap perkembangan tertentu. Super (Savickas, 2002) menjelaskan tahap perkembangan pada siswa SMK masuk dalam tahap exploration (14-24 tahun), pada sub tahap tentative (14-17 tahun) yaitu menentukan pilihan pekerjaan, menggunakan pilihan dan dapat melihat bidang serta tingkat pekerjaan yang sesuai dengan dirinya. Super (Crews, 2006) mengemukakan kematangan karir meliputi lima elemen: career planning: kemampuan untuk belajar dari pengalaman dan mengantisipasi masa depan (perencanaan penuh); career exploration: kemampuan untuk mengajukan pertanyaan dan mengumpulkan informasi dan kemampuan untuk berinteraksi di masyarakat, di sekolah, dan dengan anggota keluarga (ekplorasi); information gathering: kemampuan untuk mengumpulkan informasi tentang kerja; decision-making: kemampuan untuk membuat pilihan berdasarkan pengetahuan keputusan karir membuat prinsip-prinsip (pengambilan keputusan strategis); career orientation: kemampuan untuk mengembangkan kesadaran diri, diri berwawasan, dan menetapkan pilihan yang realistis dan sesuai dengan preferensi (orientasi realitas). Individu yang memiliki kematangan karir mampu belajar dari pengalaman, mampu mencari informasi berinteraksi di masyarakat, mampu mencari dan mengumpulkan informasi dunia kerja, mampu membuat keputusan karir, dan mengembangkan kesadaran diri untuk berwawasan luas serta menetapkan pilihan yang realistis (Crews, 2006 ). rendahnya kematangan karir dapat menyebabkan kesalahan dalam mengambil keputusan karir, termasuk kesalahan dalam menentukan jurusan pendidikan bagi siswa SMA (Wijaya 2010)

Salah satu SMK yang memiliki perhatian cukup besar terhadap persiapan karir siswanya adalah SMK Negri 1 Bantul. Berdasar wawancara banyak siswa kelas XI menyampaikan bahwa ada diantara siswa kelas XI berkonsultasi dengan guru Bimbingan Konseling (BK) mengenai permaslaahan karirnya maupun masalahmasalah pribadi. Para siswa menyakan mengenai pilihan karir apa paling sesuai untuk dirinya. Kemampuan yang dibutuhkan untuk diterima pada suatu pekerjaan atau perusahaan. Siswa juga berkonsultasi mengenai pilihan karir apa yang memiliki prosek baik serta masalah-masalah pribadi yang dirasakan dapat menghambat karirnya. Siswa yang lebih banyak berkonsultasi ke BK adalah siswa kelas XII yang sudah mampu mempersiapkan karir dan siap untuk bekerja setealh lulus. Hal tersebut menujukkan bahwa masih banyak siswa di SMK Negri 1 yang belum memahami tujuan karirnya, dengan kata lain belum memiliki kematangan karir.

Kematangan karir berkaitan erat dengan faktor internal meliputi inteligensi, bakat, minat, kepribadian, harga diri, dan nilai. Salah satu yang mempengaruhi adalah kepribadian. locus of control. Locus of control (LOC) adalah keyakinan individu mengenai hubungan antara perilaku dan konsekuensi yang diperolehnya (Slavin, 1997). LOC dibagi menjadi internal dan eksternal. Locus of control (LOC) internal adalah keyakinan individu terhadap segala sesuatu yang terjadi pada dirinya, karena faktor dari dalam diri, sedangkan locus of control (LOC) eksternal adalah faktor 
dari luar yang mempengaruhi keberhasilan individu (Phares, 1976).

LOC internal adalah keyakinan individu terhadap segala sesuatu yang terjadi pada dirinya, karena faktor dari dalam diri, kemampuan, minat dan usaha dalam diri individu akan mempengaruhi keberhasilan individu itu. Orang dengan LOC internal lebih berorientasi pada keberhasilan karena mereka menganggap perilaku mereka dapat menghasilkan efek positif dan juga mereka lebih cenderung tergolong high-achivever Phares (Crews, 2006). Seseorang yang memiliki LOC internal yang tinggi memiliki cirri yaitu: kerja keras, inisiatif tinggi, pemecahan masalah, berfikir efektif dan persepsi keberhasilan, Crider (O’Driscoll, 2006).

Individu dengan LOC internal ketika dihadapkan pada pemilihan karir maka akan melakukan usaha untuk mengenal diri, mencaritahu tentang pekerjaan dan langkah-langkah pendidikan, serta berusaha mengatasi masalah yang dihadapi dan membuat kematangan karir semakin tinggi (Taganing, 2007). LOC memiliki dampak yang memainkan peranan penting dalam beragam ranah kehidupan seseorang, termasuk dalam hal kesehatan, kebahagiaan, kepuasan kerja, dan kehidupan secara keseluruhan, dan dalam tingkat yang cukup luas, berpengaruh pula pada karir dan pilihan dan kejuruan yang mereka pilih, (O'Driscoll, 2006). Berdasarkan uraian di atas perlu dikaji lebih lanjut mengenai hubungan antara LOC internal dengan kematangan karir pada siswa SMK N 1 Bantul.

\section{Metode Penelitian}

Penelitian ini melibatkan 150 orang siswa kelas XI SMK Negri 1 Bantul dari lima kelas yang pilih secara acak dengan teknik cluster random sampling. Data dikumpulkan dengan menggunakan skala LOC Internal dan skala kematangan karir yang disusun oleh peneliti dan telah diujicobakan. Skala LOC Internal terdiri dari 30 item yang memiliki koefisien reliabilitas $\left(r_{t}\right)$ sebesar 0,923 dengan korelasi item total bergerak 0,329 sampai dengan 0,692 sehingga dapat dikatakan valid dan handal untuk digunakan sebagai alat pengumpul data. Skala kematangan karir terdiri atas 30 item dengan koefisien reliabilitas $\left(r_{t t}\right)$ sebesar 0,925 dan korelasi item total bergerak 0,374 sampai dengan 0,636, sehingga skala Kematangan Karir dapat dikatakan valid dan handal untuk digunakan sebagai alat pengumpul data. Metode analisis data yang digunakan untuk menguji hubugan dua varibel dalam penelitian adalah teknik korelasi Product Moment dari Pearson.

\section{Hasil dan Pembahasan}

Hasil uji korelasi product moment antara LOC Internal dan Kematangan Karir didapatkan koefisien korelasi (r) sebesar 0,161 dan $\mathrm{p}=0,049(\mathrm{p}<0,05)$ dapat disimpulkan bahwa terdapat hubungan positif yang signifikan antara LOC Internal dengan Kematangan Karir.

Tabel 1. Hasil analis korelasi LOC internal dengan kematanga karir

\begin{tabular}{cccc}
\hline $\begin{array}{c}\text { Nama } \\
\text { variabel yang } \\
\text { dikorelasikan }\end{array}$ & $\mathbf{R}$ & $\mathbf{P}$ & Keterangan \\
\hline $\begin{array}{c}\text { LOC Internal } \\
\text { dan Kematangan } \\
\text { Karir }\end{array}$ & 0,161 & 0,049 & Positif \\
\hline
\end{tabular}

Hasil analisis statistik menunjukkan bahwa terdapat hubungan positif yang signifikan antara LOC Internal dengan kematangan karir. Penelitian ini mendukung penelitian yang sebelumnya yang menyatakan keterkaitan LOC ialah 
penelitian yang dilakukan oleh ariyani (2014) yang menemukan bahwa terdapat hubungan yang signifikan antara LOC internal dengan kematangan karir.

Individu yang memiliki LOC internal yang tinggi percaya bahwa kemampuan dan usaha yang akan menentukan keberhasilannya. Keyakinan akan kemampuan dan usaha mendorongnya untuk bekerja keras, memiliki inisiatif untuk melakukan hal baru secara mandiri. Individu ini juga kan mampu berpikir efektif untuk mengatasi masalah dan percaya bahwa usaha harus dilakukan jika ingin mencapai keberhasilan Crider, (O’Driscoll, 2006).

Individu yang kecenderungan dengan LOC internal memiliki keyakinan bahwa kejadian yang dialami merupakan akibat dari perilaku dan tindakannya sendiri. Hal ini mebuatnya mampu memiliki kendali yang baik terhadap perilakunya sendiri, cenderung dapat mempengaruhi orang lain, yakin bahwa usahanya dapat berhasil. Individu dengan kecenderungan loc internal akan aktif mencari informasi dan pengetahuan terkait situasi yang sedang dijalani, Rotter (Friedman dan Schustack, 2006). Dalam kaitannya dengan kematangan karir, individu dengan LOC internal yang tinggi akan menunjukkan kemauan untuk bekerja keras mengumpulkan informasi-informasi tentang karir secara mandiri seperti bidang pekerjaan, persyatan yang harus dipenuhi pada pekerjaan tertentu dimasa mendatang (information gathering). Informasi tersebut akan meningkatkan pengetahuan yang akan digunakan dalam merencanakan karirnya.

LOC internal juga berkaitan dengan keyakinan individu bahwa keberhasilan yang diraih sebanding dengan usaha yang mereka lakukan dan sebagian besar dapat mereka kendalikan. Karakteristik yang menunjang yaitu selalu mempunyai persepsi bahwa usaha harus dilakukan jika ingin berhasil. Orang dengan internal locus of control lebih berorientasi pada keberhasilan karena mereka menganggap perilaku mereka dapat menghasilkan efek positif dan juga mereka lebih cenderung tergolong highachivever, Findley dan Cooper (Friedman dan Schustack, 2006).

Memiliki inisiatif tinggi merupakan karakteristik lain dari individu dengan kecenderungan LOC internal. Inisiatif yang tinggi akan mempengaruhi individu dalam belajar dari pengalaman sehingga mampu mengantisipasi masa depannya (career planning). Inisiatif tinggi tidak luput dari kemampuan individu dalam mengajukan pertanyaan dan mengumpulkan informasi guna berinteraksi dengan berbagai elemen masyarakat, sekolah dan keluarga (career exploration). Menurut Rogers (Muhibin, 2010) Individu akan berhasil ketika belajar dari inisiatifnya sendiri kemudian akan untuk mengumpulkan informasi tentang dunia kerja secara mandiri, dengan inisiatif dari dalam diri dengan melibatkan perasaan dirinya maka individu akan memiliki kesadaran untuk terus mengembangakan wawasannya (career orientation).

Upaya pencapaian tujuan karirnya, individu seringkali dihadapkan situasi yang tidak sesuai dengan harapan atau menghadapi kesulitan atau hambatan. Inidvidu dengan LOC internal yang tinggi akan selalu berusaha menemukan pemecahan masalah yang dihadapinya dan mampu berfikir secara efektif dalam membuat keputusan karir (decision making). Individu dengan LOC internal percaya mereka mempunyai kemampuan menghadapi tantangan dan ancaman yang timbul dari lingkungan dan berusaha memecahkan masalah dengan keyakinan yang tinggi Brownel (Shaffer, 2009). Pemecahan masalah karir adalah seperangkat proses berpikir yang melibatkan analisis penyebab, perumusan dan 
pembuatan alternative tindakan. Masalah karir terselesaikan jika pilihan karir yang diambil adalah alternative yang layak, (Peterson, Lumsden, Redearson, \& Lenz, 2002)

Berdasarkan hasil analisis data, 70.4\% sampel memiliki LOC internal dalam ketegori yang tinggi dan $29.3 \%$ dalam kategori sedang. Hal ini dipengaruhi oleh usaha yang dilakukan pihak sekolah untuk mendukung pengembangan kepribdian siswa melalui pelatihan motivasi yang diberikan pada siswa. SMK Negri 1 Bantul secara rutin melakukan pelatihan motivasi kepada siswa setiap seminggu sekali dengan cara memasuki tiap kelas dan bertujuan meninjau dan menumbuhkan semangat siswanya dalam menghadapi problema yang akan dihadapinya, disisi lain sekolah juga memberikan faslitas yang mendukung kematangan karir siswa melalui program sekolah yaitu diantaranya; KI (Kunjungan Industri), papan bimbingan yang berisi informasi dunia kerja, adanya ruang BK dan staff BK yang selalu bersedia jika dimintai informasi bagi siswa. Sekolah juga menyediakan fasilitas komputer yag dilengkapi ineternet untuk merangsang siswa mencari informasi dunia kerja dan sekolah juga mendatangkan ahli untuk mengisi seminar karir. Fasilitas yang diberikan sekolah dalam rangka menunjang kematangan karir siswa terbukti mampu membuat para siswa SMK N 1 Bantul menjadi matang dalam kesiapan karirnya dilihat dari hasil olah data dengan 78\% pada kategori tinggi dan $72 \%$ pada kategori sedang yang artinya kematangan karir siswa tergolong baik.

Siswa degan Locus of Control Internal yang tinggi ketika dihadapkan dengan pemilihan karir, maka individu akan melakukan usaha untuk mengenali diri, mencari tahu tentang pekerjaan dan langkah-langkah pendidikan, serta berusaha mengatasi masalah yang berkaitan. Hal ini sesuai dengan teori yang di kemukakan Super (dalam Winkel, 2012) menjelaskan bahwa individu dikatakan matang atau siap membuat keputusan karir jika pengetahuan yang dimilikinya untuk membuat keputusan karir didukung oleh informasi yang kuat mengenai pekerjaan berdasarkan eksplorasi yang telah dilakukan.

Penelitian lain yang mendukung bahwa kematangan karir penting adalah penelitian yang dilakukan oleh Wijaya (2010) menyatakan bahwa kematangan karir amatlah penting dalam menentukan jurusan pendidikan yang tepat, siswa yang kurang memiliki kesadaran mengenai kemampuan dan minat yang dimiliki dirinya dapat memiliki persepsi yang salah tentang karir yang akan dipilih dan kurang termotivasi dalam menjalankan bidang karir yang dipilihnya.

\section{Simpulan}

Berdasarkan hasil pembahasan dapat dapat simpulkan bahwa kemtangan karir siswa berhubungan dengan locus of control internal pada siswa. Semakin tinggi locus of control internal, maka semakin tinggi kematangan karir pada siswa. sekolah memiliki peran yang besar dalam locus of control internal dan kematangan karir siswa. dukungan sekolah berupa pelatihan motivasi membantu siswa mengembangkan locus of control internalnya. Fasilitas sekolah berperan dalam memberikan kesempatan bagi siswa untuk mengakses informasi dan pengembangan wawasan yang mendukung kematangan karirnya. Penelitian selanjutnya perlu mengkaji faktor-faktor lain yang berpengaruh terhadap kematangan karir, baik dari faktor internal dan eksternal. Sekolah perlu menyiapkan karir sejak dini dari kelas 
$\mathrm{X}$ sehingga siswa memiliki kesempatan yang cukup dalam menentukan tujuan karir yang jelas, memiliki perencanaan dan menjalankan perencanaan dalam mencapai tujuan karir. Siswa diharapkan membangun kesadaran diri akan pentingnya menyiapkan karir sejak dini.

\section{Daftar Pustaka}

Ariyani, E. (2014). Pengaruh Internal Locus of Control terhadap Kematangan Karir Siswa Madrasah Aliyah Negeri 2 Samarinda. Jurnal Imiah, 2(2).

Badan Pusat Statistik. (2014). Berita Resmi Statistik Agustus 2014. http://www. bps.go.id/Brs/view/id/234. Diakses Tanggal 02 Maret 2015.

Betz, N.E. \& Luzzo, D. (1996). Career assessment and the Career DecisionMaking Self-Efficacy Scale. Journal of Career Assessment, 4, 313-328.

Crews , M. E. (2006). The Career Maturity of College Freshmen as Impacted by Career Counseling Received in grades $K-12$ : A reflective study. Diunduh dari https://books. google.co.id/books?id=Sns61jcuUrMC\&pg=PA4\&dq=career + maturity \&hl=id\&sa $=$ X\&ei $=$ hBkQVbfnBsqiugS_4oKgDg\&ved $=0 \mathrm{CBsQ6A}$ EwAA\# $\mathrm{v}=$ onepage $\& \mathrm{q}=$ career $\% 20$ maturity $\& \mathrm{f}=$ false.

Direktorat Tenaga Kependidikan. (2008). Bimbingan dan Konseling di Sekolah. Jakarta: Direktorat Jenderal PMPTK.

Friedman dan Schustack. (2006). Psikologi Kepribadian: Teori Klasik dan Modern. Jakarta: Erlangga.

Muhibin, S. (2010). Psikologi Pendidikan dengan Pendekatan Baru. Bandung:
PT. Remaja Rosdakarya.

O'Driscoll, M. (2006). Locus of Control. In Jeffrey H. Greenhaus and Gerard A. Callanan, (Eds.), Encyclopedia of Career Development. Diunduh dari https://books.google. co.id/books?id=Jf1yAwAAQBA$\mathrm{J} \& \mathrm{pg}=$ P T $518 \& 1 \mathrm{pg}=$ P T $518 \& \mathrm{~d}-$ $\mathrm{q}=$ Locus + of + Control. + In + Jeffrey + H. + Greenhaus + and + Gerard + A. Callanan,+\%28Eds.\%29,+Encyclopedia+of+Career+Development. \&source=bl\&ots $=$ i zL 0 S X Q o 13 \& s i g = G C 8 j D j210IHa_U9DrUqkLA9YKGw\&hl=id\&sa=X\&ei=XikWVdfiBs2nuQT7nYDIDg\&redir_es$\mathrm{c}=\mathrm{y} \# \mathrm{v}=$ onepage $\& \mathrm{q}=$ Locus $\% 20$ of $\% 20$ Control. $\% 20$ In $\% 20$ Jeffrey $\% 20$ H. \%20Greenhaus $\% 20$ and $\% 20$ Gerard\%20A.Callanan\%2C\%20 $\% 28$ Eds. $\% 29 \% 2 \mathrm{C} \% 20$ Encyclopedia\%20of\%20Career\%20Development. $\& \mathrm{f}=$ false

Peterson, G.W., Lumsden, J. A., Redearson, R. C., \& Lenz, J. G. (2002). A Cognitive Information Processing Approach to Career Problem Solving and Decision Making (D. Brown \& Associates, Ed). San Francisco: John Wiley \& Sons, Inc.

Phares, E.J. (1976). Locus of control in personality. Morristown, N.J.: General Learning Press

Savickas, M. L. (2001). A Developmental Perspective on Vocational Behavior: Career Pattern, Salience, and Themes. International Journal for Educational and Vocational Guidance, 1, 49-57.

Savickas, M. L. (2002). Career Construction. A Development theory of vocational 
behavior. Dalam d. brown. 4 associates (eds), career choice and development, (4 th ed). San Francisco: jussey-bass.

Seligman, L. (1994). Developmental career counseling and assessment. Thousand oaks: sage publications.

Shaffer, D. (2009). Social and Personality Development. Diunduh dari http://books.google.co.id/ books?id=PErZTQ7LkmwC\&p$\mathrm{g}=\mathrm{PA} 216 \& \mathrm{dq}=$ some + one + with + internal+locus + of + control+will\&hl $=$ jv\&ved=oahUKEwiq8NydyLzKAhUMSY4KHUTUC4A4ChDrAQg$4 \mathrm{MAU} \# \mathrm{v}=$ onepage $\& \mathrm{q}=$ some $\% 20$ one $\% 20$ with $\% 20$ internal $\% 20$ locus $\% 20$ of $\% 20$ control $\% 20$ will $\& f=$ false 22 Januari 2016.

Slavin, R E. 1997. Educational Psychology Theory, Reseach, and Pratise. Dalam Trianto,. 2011. Mendesain Model Pembelajaran Inovatif-Progresif. Ed ke-4. Jakarta: Kencana.

Taganing, K. N. M., (2007). Pengaruh Locus of Control dan Efikasi Diri terhadap Kematangan Karir Siswa Sekolah
Menengah Atas (SMA). Proceeding PESAT. Diunduh dari http://ejournal. gunadarma.ac.id/files/anita $\% 20 z \% 20$ taganing $\% 20$ pengaruh $\% 20$ locus $\% 20$ of.pdf

Tim Pengembang Ilmu Pedidikan FIPUPI. (2007). Ilmu Aplikasi dan Ilmu Pedidikan (bagian 2). Badung: PT IMTIMA.

Wijaya. F. (2010). Hubungan Antara Kematangan Karir dengan Motivasi Belajar Pada Siswa Kelas X MAN Cibinong. Diunduh dari http://ejurnal. untag-smd.ac.id

Winkel, W.S. \& Hastuti, M.M.S. (2004). Bimbingan dan Konseling di Institusi

Pendidikan. Yogyakarta: Media Abadi.

Winkel, W.S. \& Hastuti, M.M.S. .(2007). Bimbingan dan Konseling Diinstitusi Pendidikan. Yogjakarta: Media Abadi.

Winkel, W.S. \& Hastuti, M.M.S. (2012). Bimbingan dan Konseling Diinstitusi Pendidikan. Yogjakarta: Media Abadi. 